\title{
Assessment of Heavy Metal Pollution of Greenhouse Areas in the Eastern Part of Antalya (Turkey)
}

\author{
BÜLENT TOPCUOĞLU
}

Akdeniz University Vocational School of Technical Sciences, 07058 Antalya TURKEY

\begin{abstract}
To assess the heavy metal pollution of intensive greenhouse regions of east Antalya, and to understand the ecological risk and transport processes of heavy metals in an agricultural ecosystem and the relations with the soil characteristics; a survey study was conducted on greenhouse plants, groundwater properties and heavy metal characteristics in intensive greenhouse areas of east Antalya, one of the major greenhouse production region of Antalya-Turkey. Additional to routine water and soil analysis, a sequential extraction procedure was used to estimate the availability of heavy metals $(\mathrm{Zn}, \mathrm{Cd}, \mathrm{Ni}$ and $\mathrm{Pb}$ ) in greenhouse soils and several environmental pollution indexes were used to evaluate the size of pollution and risks.

Groundwaters of greenhouse area have low conductivity but high nitrate content. Heavy metal contents of groundwaters were below the permissible levels and, the average heavy metal evaluation index (HEI) values for all metals in groundwaters were below the critical value.

The total concentrations of $\mathrm{Cd}, \mathrm{Ni}$ and As in all soils of East Antalya greenhouses were generally above the referenced limits. Soil metal speciation showed that the greatest percentage of all metals was present in the residual form, and the mobility of metals declined in the following order: $\mathrm{As}>\mathrm{Zn}>\mathrm{Cd}>\mathrm{Ni}>\mathrm{Pb}$. Single factor and composite pollution coefficient values of all metals were not exceeded critical limits. Anthropogenic and enrichment factor indexes of greenhouse soils indicate that both two parameter showed similar trends and 1,5 to 5 fold metal enrichment by anthropogenic inputs compared to uncontaminated soil. Potential ecological risk indexes of soil metals were found below the threshold value that indicate these metals have a low risk to surrounding environment.

All heavy metal concentrations except $C d$ in greenhouse tomato fruits were found below the permissible heavy metal limits. However, target hazard quotient of tomato fruits was found below the critical value and thus it can be presumable that no health risk for Cd metal in short or medium terms.
\end{abstract}

Keywords: Greenhouse area, Metal Pollution, Metal Speciation

\section{Introduction}

Due to intensive use of agrochemicals in greenhouse soils, heavy metals are become to common pollutants in greenhouse soils and adjacent environment. Repeated amendments of organic matter and intensive use of fertilizers, metal-enriched chemicals and biocides may cause soil and environmental pollution in greenhouses. Although greenhouse areas a have great impact on environment due to intensive use of agrochemicals, little attention has been paid to metal accumulation in greenhouse plants, metal contents of ground waters around greenhouses and heavy metal speciation and metal bioavailability and environmental pollution assessment in greenhouse soils with respect to comprehensive and integrated environmental evaluation.

The impact of agricultural activity on water sources has been widely acknowledged and its impact on surface water systems has been described in numerous studies [1]. Especially, the relationship between agricultural practices and the dissolution of nitrate in groundwater, as well as other pollutants have been studied in a number of case studies [2].

Most of recently reported studies dealing with the evaluation of heavy metal contamination in soils use only the total content of heavy metal as a criterion for determining their potential effect on the environments. However, total concentrations of heavy metals provide inadequate information for assessing their bioavailability or toxicity [3].

Today many environmental pollution risk indexes developed for water and sediments can be used for soils, organic matter and other environmental materials. Although several establishment criteria developed for soils 
depend on total concentrations, these criteria were frequently unsatisfied for a comprehensive environmental risk prediction.

The aim of this study was to provide information on the metal accumulation in ground water and greenhouse plants, metal speciation and metal bioavailability in the greenhouse soils and also evaluate metal enrichments in ground waters, greenhouse soils and plants and paradoxes of soil metal establisments and soil pollution indexes versus to soil characteristics in greenhouse soils of East Antalya Region.

\section{Material and Methods}

The experiment was conducted on the major greenhouse vegetable growing area located at east Antalya (including Serik, Manavgat and Alanya regions), Turkey. The site studied is intensively cultivated and is not industrialized area. The experiment was carried out at greenhouse region and soil samples were taken from 9 sub-region and 26 sampling points (Fig. 1).

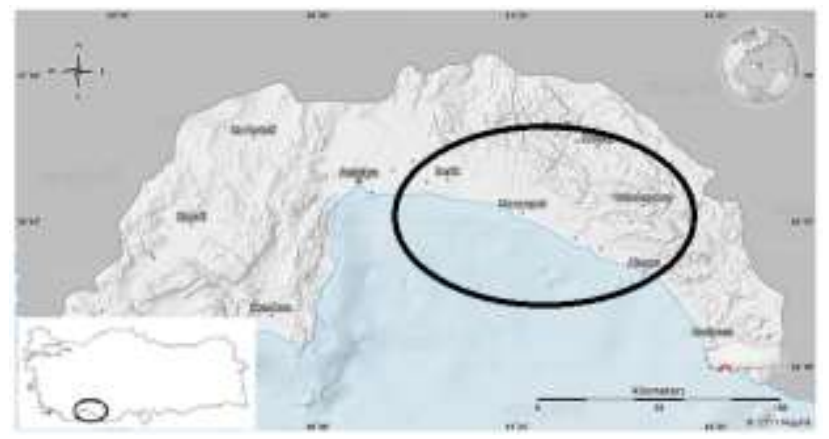

Fig. 1: Map of Antalya, Turkey

The geological materials of greenhouse area are mainly of calcareous nature and adjacent to Mediterranean sea with average $57,8 \mathrm{~m}$ altitude. The land is influenced by a Mediterranean climate with a high average annual rainfall (1081,5 mm/year), the annual average temperature being around $18,7{ }^{\circ} \mathrm{C}, 63,8 \%$ average humidity and average 164 sunny days per year. As for greenhouses, the annual temperature is higher inside than outside, and most of them are watered by sprinklers with ground water source at the same point. All greenhouses have passive ventilation to control temperature and humidity inside. A great number of greenhouse soils is artificially built up with a different layer of sand, organic matter and other soil source.

Groundwater samples were collected from five greenhouse sites to analyze for heavy metals and other properties. Water samples were collected in polyethylene bottles (washed with detergent then with doubledistilled water followed by $2 \mathrm{M}$ nitric acid, then double-distilled water again and finally with sampled water). Water samples were acidified with $10 \%$ HNO3 for metal analysis, brought to the laboratory and kept refrigerated until needed for analysis. $\mathrm{pH}$, electrical conductivity (EC) and nitrate were measured on site.

To determine heavy metals in water samples, $10 \mathrm{ml}$ of aqua regia and $1 \mathrm{ml}$ of perchloric acid added to 100 $\mathrm{ml}$ of water samples in a culture test tube, then incubated at $80^{\circ} \mathrm{C}$ in a water bath, after total digestion and subsequent cooling, the solution was diluted to $50 \mathrm{ml}$ and analyzed for heavy metals.

Greenhouse soil samples were taken at a depth of $10-20 \mathrm{~cm}$ and these were air-dried, sieved $(<2 \mathrm{~mm})$ and stored in polyethylene bags sealed awaiting analysis.

Electrical conductivity (EC) and $\mathrm{pH}$ were measured a soil:water ratio of 1:2. cation exchange capacity (CEC) was determined by $0.1 \mathrm{M}$ NN4AoC extraction; $\mathrm{CaCO} 3$ content was determined by the calcimeter; organic carbon was measured by wet oxidation; and texture was determined by Bouyoucos hydrometer method.

Sequental extraction method [4] was applied to soil samples to identify metal fractions.

For the determination of 'total' heavy metal concentrations, soil samples were digested in aqua regia (1:3 $\mathrm{HNO} 3 / \mathrm{HCl}$ ) and $\mathrm{HCLO} 4$ according to the international standard [5] $\mathrm{Zn}, \mathrm{Cd}, \mathrm{Ni}$ and $\mathrm{Pb}$ concentrations of water 
and greenhouse soil samples were analysed using ICP-MS under optimised measurement conditions, and values were adjusted for oven dried $\left(12 \mathrm{~h}\right.$ at $\left.105^{\circ} \mathrm{C}\right)$ material.

Selected environmental pollution indexes for water samples 'Heavy Metal Evaluation Index (HEI) of the Groundwaters' [6], as for soil samples 'Mobility of Metals' [7], 'Single-Factor and Composite Pollution Index of Soils' [8], Anthropogenic Factor (AF) [9] and 'Enrichment Factor (EF) Indexes of Soil' [10], 'Potential Ecological Risk Factor Indexes' [11], and as for plant samples 'Heavy Metal Transfer (Bioconcentration) Factor' and 'Target Hazard Quotient (THQ) of Food' [12], Hazard Index (HI) [13] were used for comprehensive and integrated evaluation of parameters.

Statistical analyses were performed by using SPSS-16 for Windows program.

\section{Result and Discussion}

\subsection{Groundwater Properties}

Certain groundwater characteristics and total heavy metal contents of greenhouse areas are shown in Table 1. Groundwaters in greenhouse areas have ranged slightly alkaline and slightly acidic reaction, low electrical conductivity. Total nitrate content of groundwater was generally below the permissible limit, but in some sampling sites nitrate concentrations has exceeded maximum permissible limits for drinking waters. High concentration of nitrate in these areas is of course may be due to highly intensive agricultural practices for all season. Average total $\mathrm{Cd}, \mathrm{Pb}, \mathrm{Ni}$ and $\mathrm{As}$ contents of ground waters in all greenhouse areas were below the permissible pollution limits.

TABLE I: The analytical characteristics and heavy metal concentrations of the groundwaters

\begin{tabular}{|c|c|c|c|c|c|c|c|c|}
\hline Site & $\mathrm{pH}$ & $\begin{array}{c}\text { EC, } \\
\mu \mathrm{S} \mathrm{cm}^{-1}\end{array}$ & $\begin{array}{c}\mathrm{NO}_{3}, \\
\mathrm{mg} \mathrm{L}^{-1}\end{array}$ & $\mathrm{Zn}, \mu \mathrm{gL}^{-1}$ & $\mathrm{Cd}, \mu \mathrm{g} \mathrm{L}^{-1}$ & $\begin{array}{c}\mathrm{Pb} \\
\mu \mathrm{g} \mathrm{L}^{-1}\end{array}$ & $\mathrm{Ni}, \mu \mathrm{gL}^{-1}$ & As, $\mu \mathrm{g} \mathrm{L}^{-1}$ \\
\hline 1 & 7,25 & 777,7 & 27,0 & 178 & 0,013 & 2,87 & 4,03 & 17,80 \\
\hline 2 & 7,54 & 944,2 & 54,5 & 158 & 0,055 & 2,32 & 3,43 & 18,04 \\
\hline 3 & 7,58 & 1038,5 & 57,5 & 280 & 0,060 & 3,04 & 4,29 & 16,50 \\
\hline 4 & 7,56 & 913,8 & 41,2 & 257 & 0,038 & 4,00 & 7,16 & 14,24 \\
\hline 5 & 8,04 & 283,0 & 44,3 & 175 & 0,053 & 1,73 & 3,60 & 19,63 \\
\hline 6 & 8,19 & 354,0 & 43,0 & 171 & 0,100 & 1,41 & 3,55 & 18,38 \\
\hline 7 & 8,02 & 288,0 & 36,0 & 50 & 0,040 & 3,81 & 11,15 & 19,95 \\
\hline 8 & 7,74 & 1016,5 & 74,5 & 37 & 0,245 & 5,27 & 1,02 & 16,73 \\
\hline 9 & 7,08 & 517,5 & 25,5 & 46 & 0,048 & 4,18 & 3,05 & 20,87 \\
\hline Mean & 7,6667 & $6,8147 \mathrm{E} 2$ & 44,8333 & $1,5022 \mathrm{E} 2$ & 0,0724 & 3,1811 & 4,5867 & 18,0156 \\
\hline St.D. & 0,37 & 3,20 & \begin{tabular}{|l|}
1,54 \\
\end{tabular} & 8,93 & 0,069 & 1,25 & 2,92 & \begin{tabular}{|l|}
2,02 \\
\end{tabular} \\
\hline Limits[12] & & & 50 & 200 & 3 & 20 & 10 & 20 \\
\hline
\end{tabular}

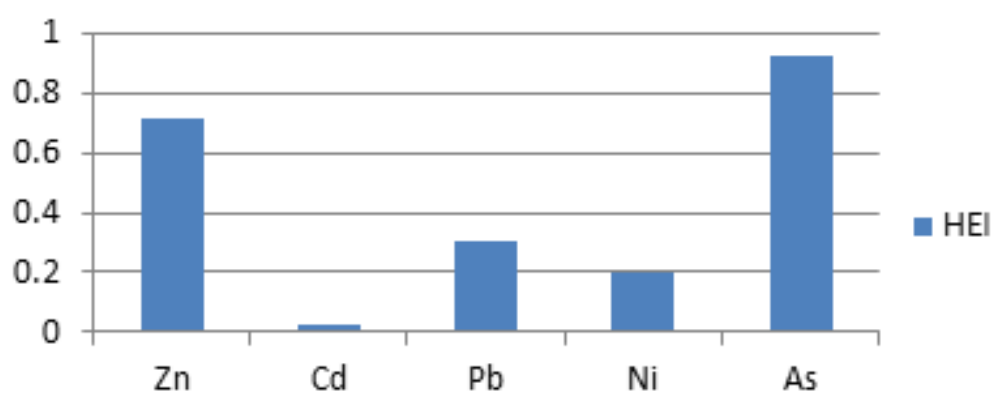

Fig. 2: Heavy metal evaluation index (HEI) of the groundwaters.

The mean heavy metal evaluation index (HEI) values for all of metals in groundwaters were below the critical value 40. Thus, all of groundwater samples may be considered as less contaminated by heavy metals and may be acceptable clean. 


\subsection{Soil Properties}

Certain soil characteristics and heavy metal contents of greenhouse areas of east Antalya are shown in Table 2 and Table 3. These greenhouse soils have generally slightly alkaline reaction, moderate CEC and low EC values. However, calcium carbonate rates were ranged low and high levels. These soil characteristics, together with irrigation by sprinklers and agricultural practices, suggest that intensive greenhouses agriculture is the main cause of soil contamination by heavy metals and that theoretically the heavy metal availability will be lower [14].

The total metal contents of the experimental soil and their pollutant limits was given in Table 3 . The results of Table 3 ranged ( $\mu \mathrm{g} g-1$ ) from 53,26 to 104,84 for zinc with a mean of 79,$67 ; 0,158$ to 0.852 for cadmium with a mean of $0.340 ; 11,52$ to 23,92 for lead with a mean of 18,$20 ; 18,38$ to 145,13 for nickel with a mean of 78,58 ; and 4,26 to 11,15 for arsenic with a mean of 7,62. Average total metal contents except zinc and lead were above the limits of european union, 86/278/EEC [15] directive to agricultural soils with $\mathrm{pH}>7$. $\mathrm{Cd}, \mathrm{Ni}$ and As concentrations in most of soil samples were higher than limit values. According to these data, the order for the average content of metals in analysed samples is $\mathrm{Zn}>\mathrm{Ni}>\mathrm{Pb}>\mathrm{As}>\mathrm{Cd}$.

TABLE II: The analytical characteristics of soils

\begin{tabular}{|c|c|c|c|c|c|c|}
\hline Site & $\mathrm{CaCO}_{3}, \%$ & $\mathrm{pH}\left(\mathrm{H}_{2} \mathrm{O}\right)$ & $\mathrm{EC}, \mathrm{micS} \mathrm{cm}{ }^{-1}$ & CEC, $\mathrm{meq}^{-100 \mathrm{~g}}$ & Org. C., $\mathrm{g}^{-\mathrm{kg}}$ & Clay, \% \\
\hline 1 & 22,50 & 7,65 & 712 & 17,33 & 1,37 & 8,45 \\
\hline 2 & 23,67 & 7,70 & 1312 & 21,62 & 1,60 & 9,54 \\
\hline 3 & 5,35 & 7,70 & 947 & 19,00 & 2,40 & 8,16 \\
\hline 4 & 9,45 & 7,44 & 1264 & 20,38 & 2,74 & 9,94 \\
\hline 5 & 25,20 & 7,59 & 1267 & 22,07 & 1,83 & 12,00 \\
\hline 6 & 36,70 & 7,62 & 1212 & 17,30 & 2,21 & 7,28 \\
\hline 7 & 0,90 & 7,39 & 2106 & 13,90 & 1,39 & 7,48 \\
\hline 8 & 1,80 & 7,40 & 1806 & 17,85 & 2,90 & 8,84 \\
\hline 9 & 1,72 & 7,29 & 2129 & 18,28 & 3,87 & 11,51 \\
\hline Mean & 14,14 & 7,53 & 1,41 & 18,63 & 2,25 & 9,24 \\
\hline St.D. & 1,31 & 0,15 & 4,93 & 2,51 & 0,82 & 1,66 \\
\hline
\end{tabular}

TABLE III: Total metal contents $\left(\mu \mathrm{g} \mathrm{g}^{-1}\right.$ dry wt) of the greenhouse soils and their pollutant limits

\begin{tabular}{|c|c|c|c|c|c|}
\hline Site & $\mathrm{Zn}$ & $\mathrm{Cd}$ & $\mathrm{Pb}$ & $\mathrm{Ni}$ & As \\
\hline 1 & 62,54 & 0,852 & 11,52 & 68,03 & 5,35 \\
\hline 2 & 70,92 & 0,339 & 19,04 & 90,23 & 10,82 \\
\hline 3 & 102,94 & 0,396 & 23,92 & 88,01 & 9,91 \\
\hline 4 & 101,50 & 0,363 & 18,93 & 145,13 & 5,50 \\
\hline 5 & 104,84 & 0,327 & 20,22 & 98,70 & 11,15 \\
\hline 6 & 53,26 & 0,224 & 15,31 & 86,32 & 9,86 \\
\hline 7 & 74,56 & 0,158 & 13,36 & 75,65 & 4,26 \\
\hline 8 & 75,51 & 0,212 & 18,06 & 18,38 & 5,61 \\
\hline 9 & 70,99 & 0,191 & 23,50 & 36,76 & 6,16 \\
\hline Mean & 79,67 & 0,340 & 18,20 & 78,58 & 7,62 \\
\hline St.D. & 1,88 & 0,209 & 4,22 & 3,64 & 2,74 \\
\hline Limits [14] & $20-300$ & $0,03-0,3$ & 50 & $2-20$ & $1-7$ \\
\hline
\end{tabular}

\section{Metal Speciation}

Concentrations of $\mathrm{Zn}, \mathrm{Cd}, \mathrm{Ni}, \mathrm{Pb}$ and $\mathrm{As}$ in soil fractions were given in Figure 3. Irrespective of sampling point, the distribution of metals in greenhouse soil samples generally followed the order below for the metals studied.

$\mathrm{Zn}: \mathrm{F} 3<\mathrm{F} 1<\mathrm{F} 4<\mathrm{F} 2<\mathrm{F} 5$

$\mathrm{Cd}: \mathrm{F} 4<\mathrm{F} 2<\mathrm{F} 3<\mathrm{F} 1<\mathrm{F} 5$

Ni: $\mathrm{F} 3<\mathrm{F} 2<\mathrm{F} 1<\mathrm{F} 4<\mathrm{F} 5$

$\mathrm{Pb}: \mathrm{F} 3<\mathrm{F} 1<\mathrm{F} 2<\mathrm{F} 4<\mathrm{F} 5$

As: $\mathrm{F} 3<\mathrm{F} 4<\mathrm{F} 2<\mathrm{F} 1<\mathrm{F} 5$

The study of the distribution of metals showed that the greatest percentage of all metals was present in the residual fraction (F5). However, F1,F2 and F3 fractions of Zn; Cd and As metals were higher than other metals. This property possibly give these metals a high mobility. The most mobile metal fraction was detected in As and the most immobile metal fractions were detected in $\mathrm{Pb}$ and Ni. Nickel largely $(93,46 \%)$ associated with residual phase. However, an important portion of As $(\%$ 26,28) was in labile form. The residual phase represents 
metals largely embedded in the crystal lattice of the soil fraction and should not be available for remobilization except under very harsh conditions [7].

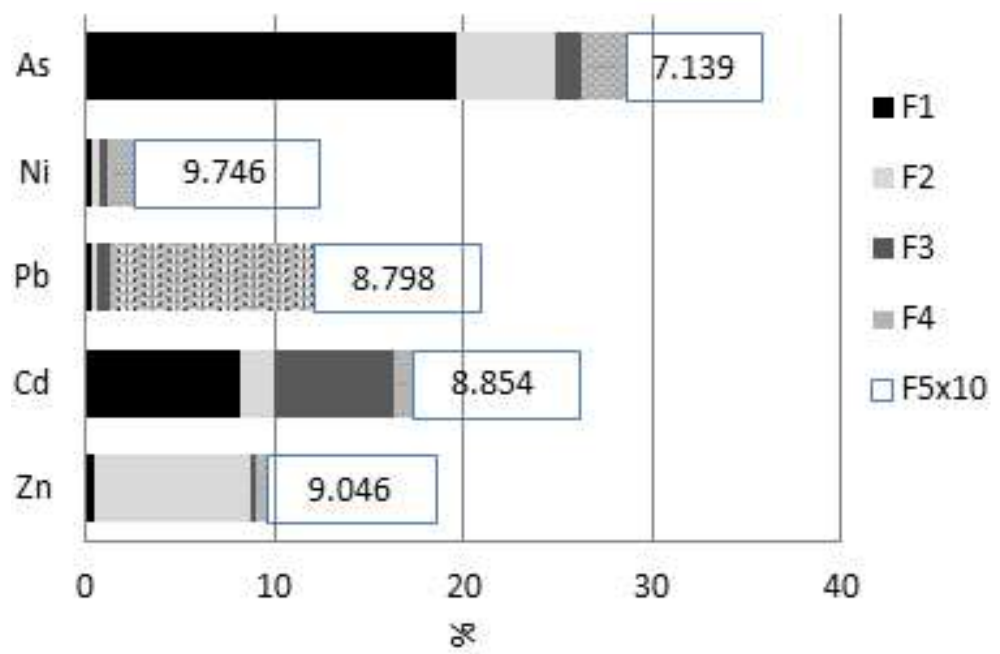

Fig. 3: Concentrations of $\mathrm{Zn}, \mathrm{Cd}, \mathrm{Ni}, \mathrm{Pb}$ and $\mathrm{As}$ in soil fractions (F5 values are higher 10 fold than given values)

\section{Mobility of metals}

Due to some metal forms are strogly bound to soil components than those exracted in F1, F3 and F3, the mobility of metals in soil samples may be evaluated on the basis of absolute and relative content of fractions weakly bound to soil component. Relative index of metal mobility was calculated as a 'mobility factor' (MF) [16] on the basis of the following equation:

$$
M F: \frac{\left(F_{1}+F_{2}+F_{3}\right)}{\left(F_{1}+F_{2}+F_{3}+F_{4}+F_{5}\right)} x 100
$$

This equation is largely describes the potential mobility of metals. The MF values were considerably higher for As, $\mathrm{Zn}$ and $\mathrm{Cd}$. The high MF values have been interpreted as symptoms of relatively high lability and biological availability of heavy metals in soils [16]. The results of the present study suggest that the mobility of the metals declines in the following order: $\mathrm{As}>\mathrm{Zn}>\mathrm{Cd}>\mathrm{Ni}>\mathrm{Pb}$ (Figure 4).

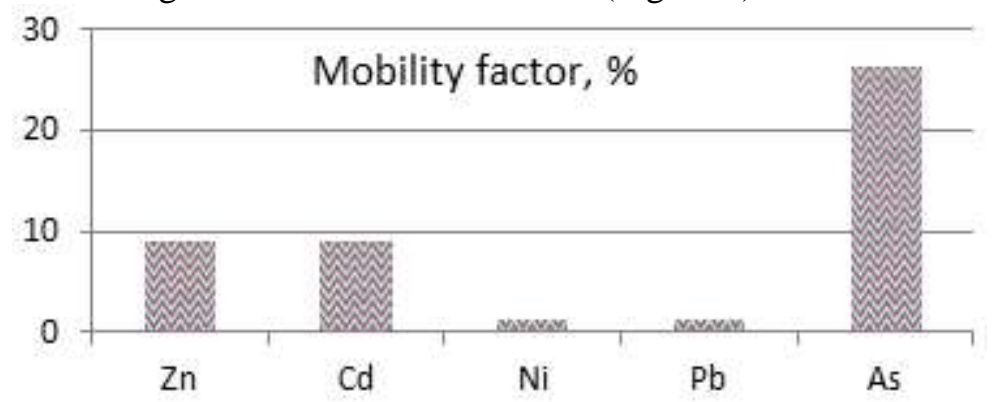

Fig. 4: Average metal mobility of greenhouse soils

\section{Contamination Evaluation of Heavy Metals}

\section{Anthropogenic Factor (AF) and Enrichment Factor $(E F)$ Indexes of Soil}

Anthropogenic and enrichment factor indexes of greenhouse soil were given in Figure 5. Estimated values of AF for the heavy metals determined in the soil samples with respect to the uncontaminated soil in the same area were generally greater than unpolluted soils. Average AF values indicate that there is 1,5 to 5 fold metal enrichment by anthropogenic inputs compared to uncontaminated soil.

Enrichment factor values were generally showed similar trends with anthropogenic factor values. But EF values of metals were found higher than AF values of metals.

Altough total As concentrations of greenhouse soils were above typical soil concentrations and permissible contaminant limits, AF and EF were detected very low. This may be inferrerred that as abundancy of parent material of soil is very high and there are less sources of contaminants of these metals. 


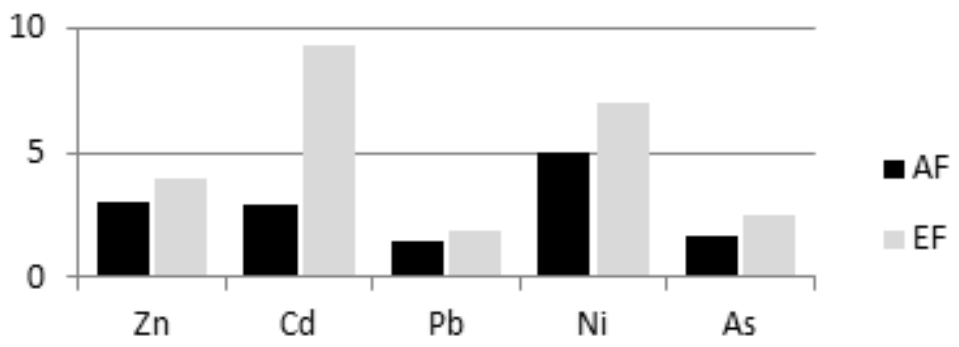

Fig. 5: Anthropogenic (AF) and enrichment factor (EF) indexes of the greenhouse soils

\section{Single-Factor Pollution Index (Pi), Composite Pollution Index (PN), Single-Factor Potential Ecological Risk Index (Er) And Potential Ecological Risk Factor Index (RI)}

Single-factor pollution index, composite pollution index, single-factor potential ecological risk index and potential ecological risk factor index of heavy metals in greenhouse soils are summarized in Figure 6. It is clear that Pi and PN coefficients were not exceeded critical value 1.

The avarage monomial risk factors, Er of heavy metals in greenhouse soils were ranked in the following order $\mathrm{Zn}<\mathrm{Ni}<\mathrm{As}<\mathrm{Cd}<\mathrm{Pb}$. The avarage monomial risk for heavy metals were found below the 40 that indicate all metals posed low risk to surrounding ecosystem. In order to quantify the overall potential ecological risk of observed metals in the greenhouse soils, general ecological risk factor (RI) value was calculated as the sum of all the risk factors. Avarage RI value were found 14,35 and below the ecological risk level.

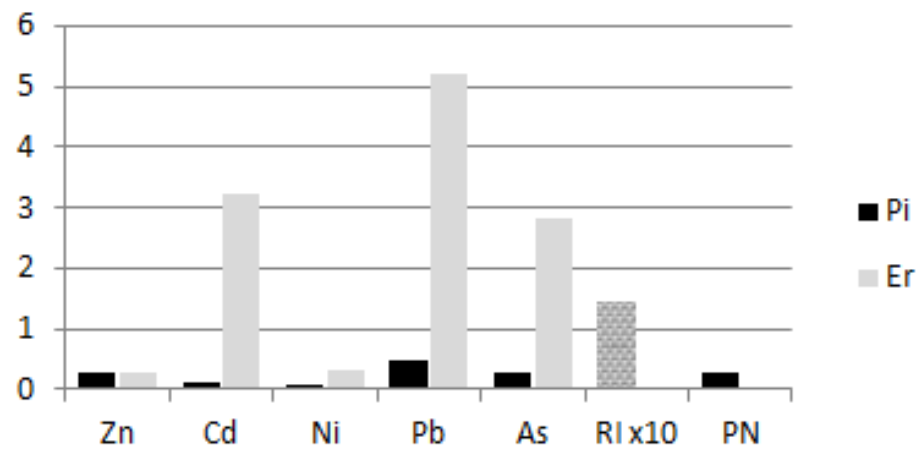

Fig. 6: Heavy metal pollution indexes of greenhouse soils (RI, value is higher 100 fold than given value)

\subsection{Plant Properties}

\section{Plant heavy metal content}

Heavy metal concentration of fresh tomato fruits are shown in Figure 7.

All heavy metal concentrations with the exception of $\mathrm{Cd}(1,674 \mathrm{mg} \mathrm{kg}-1)$ were found below the permissible heavy metal limits for fresh vegetables [17]. Although soil Ni and As concentrations were excessed the pollutant limits, concentrations of $\mathrm{Ni}$ and $\mathrm{As}$ in tomato fruit were found very low. However, it can be seen that plant high $\mathrm{Cd}$ concentrtion is affected by high soil Cd concentrations.

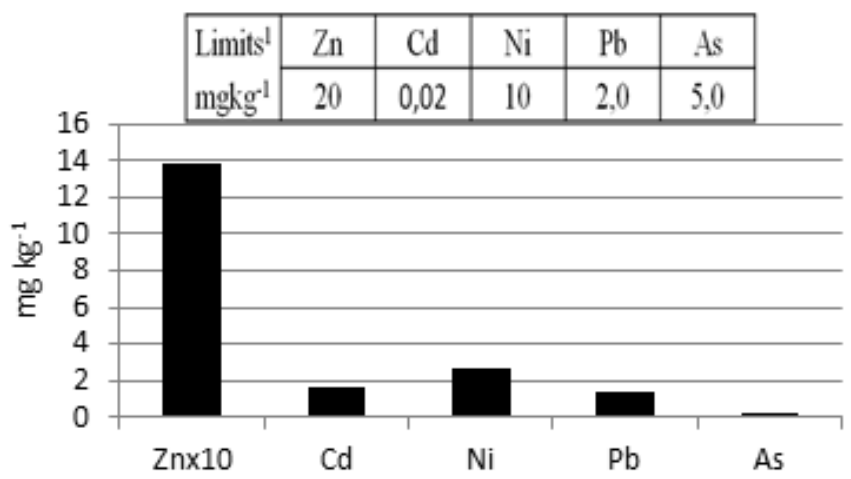

Fig. 7: Heavy metal contents of tomato fruits grown in greenhouses (Zn element value is higher 100 fold than given values) 


\section{Heavy metal transfer factor (TF), Target Hazard Quotient (THQ) and Hazard Index (HI) of Tomato Fruit}

TF, THQ and HI values are presented in Figure 8. The trend of TF value ranges were: $\mathrm{Cd}>\mathrm{Zn}>\mathrm{Ni}>\mathrm{As}>\mathrm{Pb}$. The highest avarage TF was found 3,96 for Cd in tomato fruits. The second high TF was found for $\mathrm{Zn}$ in the fruit tissues of tomato plant. These possibly might be due to higher mobility factor of $\mathrm{Cd}$ and $\mathrm{Zn}$ in the greenhouse soil (Figure 4) and may be due to soluble metal participations by agricultural practices or antropogenic factors. However, although soil As has the highest mobility factor, THQ values of As were low. The mobility of metals from soil to plants is a function of the physical and chemical properties of the soil and of plant species, and is altered by innumerable environmental and antropogenic factors [18].

High $\mathrm{Cd}$ accumulation in tomato fruits may be possibly caused by high metal mobility and high enrichment factors of soil Cd. However, although As has the most mobile metal in greenhouse soils, bioconcentration factor was low. As can be seen mean THQ values and HI values were found below the critical value 1. According to these results there can not be proposed a health risk for $\mathrm{Cd}$ metal in short or medium term.

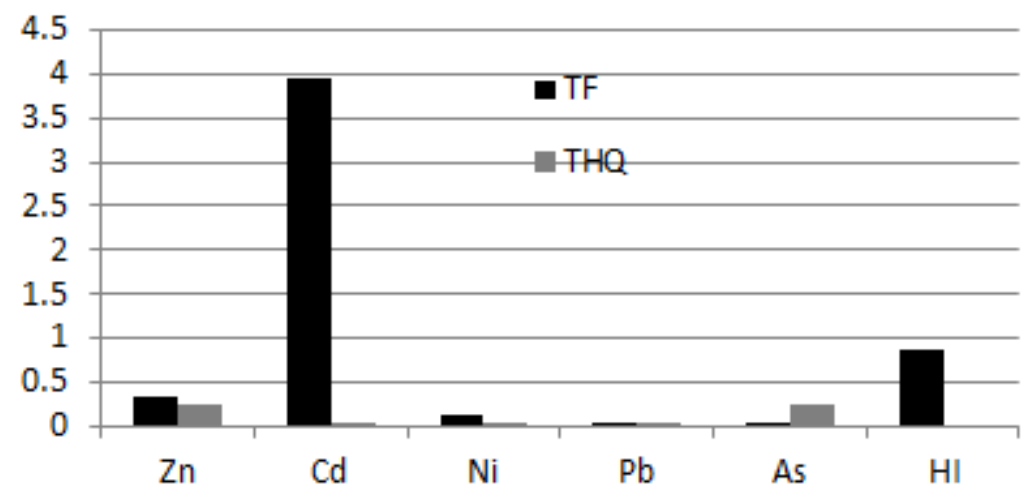

Fig. 8: Heavy metal transfer factor, Target Hazard Quotient (THQ) and hazard index (HI) of tomato

\section{Conclusions}

According to water analysis, groundwaters were not saline in nature but nitrate contents in some regions were exceeded maximum permissible limits for drinking waters. Average total $\mathrm{Zn}, \mathrm{Cd}, \mathrm{Ni}, \mathrm{Pb}$ and $\mathrm{As}$ contents were below the permissible pollution limits, and average heavy metal evaluation index (HEI) values for all metals in groundwaters were below the critical value. Thus generally, it can be concluded that all ground waters in regional size may be considered less contaminated, and in point of heavy metals and pollutants is in acceptable limits. High nitrate contents of groundwaters due to agricultural activities all season seem the main threats for public health.

The mean concentration of $\mathrm{Cd}, \mathrm{Ni}$ and As metals in all soils of East Antalya greenhouses were generally above the limits referenced by the $86 / 278$ /EEC directive to agricultural soils with $\mathrm{pH}>7$. Soil metal speciation showed that the greatest percentage of all metals was present in the residual form, and the mobility of metals declined in the following order: $\mathrm{As}>\mathrm{Zn}>\mathrm{Cd}>\mathrm{Ni}>\mathrm{Pb}$. Single factor and composite pollution coefficient values of all metals were also not exceeded critical limits. Anthropogenic and enrichment factor indexes of greenhouse soils indicate that both two parameter showed similar trends and 1,5 to 5 fold metal enrichment by anthropogenic inputs compared to uncontaminated soil.

Potential ecological risk indexes of soil metals were found below the threshold value that indicate these metals have a low risk to surrounding environment.

Concentrations of heavy metals except $\mathrm{Cd}$ in tomato fruits were found below the permissible heavy metal limits. Although soil As concentration was excessed the pollutant limits, and As has a high soil mobility factor, concentration of As in tomato fruit was found very low. According to target hazard quotient value of tomato fruit, it was found that THQ of tomato fruits was below the critical value and thus it can be presumable that no health risk for heavy metals in short or medium terms.

As it is seen, the comparision results of risk values of heavy metals based on different methods show that there are several disagreements. Most of these paradoxes in evaluation are mainly depend on the total content of heavy metals as a criterion for determining their potential effect on the environments. Whereas in a 
comprehensive manner, in addition to total concentrations, environmental risk evaluation methods and soil speciation studies will provide useful information for assessing metal bioavailability or toxicity.

\section{Acknowledgements}

This research was sponsored by TUBITAK (The Scientific and Technological Council of Turkey). Author would like to thank to TUBITAK for the financial support of the project (TOVAG-1110711).

\section{References}

[1] Cruz, J.V., Silva, M.O., Diaz, M.I., Prudencio, M.I., 2013. Groundwater composition and pollution due to agricultural practices at sete cidades volcano (Azores, Portugal). Applied Geochemistry, 29:162-173.

http://dx.doi.org/10.1016/j.apgeochem.2012.11.009

[2] Heaton, T., Stuart, M., Sapiano, M., Sultana, M., 2012. An isotope study of the sources of nitrate in Malta's groundwater. J. Hydrology, 414(415):244-254.

http://dx.doi.org/10.1016/j.jhydrol.2011.10.037

[3] Sundaray, S.K., Nayak, B.B., Lin, S., Bhatt, D., 2011. Geochemical speciation and risk assessment of heavy metals in the river estuarine sediments-A case study: Mahanadi basin, India[J]. Journal of Hazardous Materials, 186:1837-1846. http://dx.doi.org/10.1016/j.jhazmat.2010.12.081

[4] Tessier, A., Campbell, P.G.C., Bison, M., 1979. Sequental extraction procedure for the speciation of particulate trace metals. Anal. Chem. 51, 844-851.

http://dx.doi.org/10.1021/ac50043a017

[5] ISO 11446 International Standard, 1995. Soil quality-extraction of trace elements soluble in aqua regia. 03-01.

[6] Edet, A.E., Offiong, O.E., 2002. Evaluation of water quality pollution indices for heavy metal contamination monitoring. A study case from Akpabuyo-Odukpani area, Lower Cross River Basin (southeastern Nigeria), Geojournal, 57, 295-304.

http://dx.doi.org/10.1023/B:GEJO.0000007250.92458.de

[7] Yusuf, K.A., 2007. Sequental extraction of lead, copper, cadmim and zinc in soils near ojota waste site. Journal of Agronomy 6(2):331-337.

http://dx.doi.org/10.3923/ja.2007.331.337

[8] Cheng, J.L., Shi, Z., Zhu, Y.W., 2007. Assesment and mapping of environmental quality in agricultural soils of Zhejiang province, China. Journal of Environmental Sciences, 19:50-54.

http://dx.doi.org/10.1007/s11767-005-0098-6

[9] Adamu, C., I., Nganje, T.N., 2010. Heavy metal contamination of surface soil in relationship to land use patterns: A case study of Benue state, Nigeria. Materials Science and Applications, 1:127-134.

http://dx.doi.org/10.4236/msa.2010.13021

[10] Reimann, C., de Caritat, P., 2005. Distinguishing between natural and anthropogenic sources for elements in the environment: Regional geochemical surveys versus enrichment factors. The science of the total environment, 337:91107. http://dx.doi.org/10.1016/j.scitotenv.2004.06.011

[11] Hakanson, L., 1980. An ecological risk index for aquatic pollution control: A sedimentological approach. Water Research, 14: 975-1001. http://dx.doi.org/10.1016/0043-1354(80)90143-8

[12] United States, Environmental Pollution Agency (USEPA), 2007. Integrated risk information system. Available from: (http://cfpub.epa.gov/ncea/iris/index.cfm?fuseaction=iris.showSubstanceList).

[13] Xu, X., Zhao, Y., Zhao, X., Wang, Z., Deng, W., 2014. Sources of heavy metal pollution in agricultural soils of a rapidly industrializing area in the Yangtze delta of China. Ecotoxicology and Environmental Safety, 108, 161-167. http://dx.doi.org/10.1016/j.ecoenv.2014.07.001

[14] Gil, C., Boluda, R., Ramos, J. 2004. Determination and evaluation of cadmium, lead, and nickel in greenhouse soils of Almeria (Spain). Chemosphere, 55, 1027-1034.

http://dx.doi.org/10.1016/j.chemosphere.2004.01.013 
[15] C.E.C. (Council of the European Communities) 1986. Directive of 12 June 1986 on the protection of the environment, and in particular of the soil, when SS is used in agriculture (86/278/CEE). Official Journal of the European Communities, L181, 6-12.

[16] Soon, Y.K., Abboud, S., 1990. Trace elements in agricultural soils of North-western Alberta. Can.J. Soil Sci. 70, 277288.

http://dx.doi.org/10.4141/cjss90-029

[17] WHO/FAO, 2007. Joint FAO/WHO food standart programme codex alimentarius commission 13th session. Report of the thirty-eight session of the codex committee on food hygiene, Houston, USA.

[18] Zurera, G., Estrada, B., Rincon, F., Pozo, R. 1987. Lead and cadmium contamination levels in edible vegetables. Bull. Environ. Cont. Toxicol., 38:805-812.

http://dx.doi.org/10.1007/BF01616705 